\title{
Nanoparticles: Weighing the Pros and Cons from an Eco-genotoxicological Perspective
}

\author{
Preeyaporn Koedrith ${ }^{1,2 *}$, Md. Mujibur Rahman ${ }^{1, *}$, Yu Jin Jang ${ }^{3}$, Dong Yeop Shin ${ }^{3}$, Young Rok Seo ${ }^{2,3}$ \\ ${ }^{1}$ Institute of Environmental Medicine for Green Chemistry, Dongguk University Biomedi Campus, Goyang, Korea, ${ }^{2}$ Faculty \\ of Environment and Resource Studies, Mahidol University, Nakhon Pathom, Thailand, ${ }^{3}$ Department of Life Science, \\ Dongguk University Biomedi Campus, Goyang, Korea
}

\begin{abstract}
The exponential growth of nanotechnology and the industrial production have raised concerns over its impact on human and environmental health and safety (EHS). Although there has been substantial progress in the assessment of pristine nanoparticle toxicities, their EHS impacts require greater clarification. In this review, we discuss studies that have assessed nanoparticle eco-genotoxicity in different test systems and their fate in the environment as well as the considerable confounding factors that may complicate the results. We highlight key mechanisms of nanoparticle-mediated genotoxicity. Then we discuss the reliability of endpoint assays, such as the comet assay, the most favored assessment technique because of its versatility to measure low levels of DNA strand breakage, and the micronucleus assay, which is complementary to the former because of its greater ability to detect chromosomal DNA fragmentation. We also address the current recommendations on experimental design, including environmentally relevant concentrations and suitable exposure duration to avoid false-positive or -negative results. The genotoxicity of nanoparticles depends on their physicochemical features and the presence of co-pollutants. Thus, the effect of environmental processes (e.g., aggregation and agglomeration, adsorption, and transformation of nanoparticles) would account for when determining the actual genotoxicity relevant to environmental systems, and assay procedures must be standardized. Indeed, the engineered nanoparticles offer potential applications in different fields including biomedicine, environment, agriculture, and industry. Toxicological pathways and the potential risk factors related to genotoxic responses in biological organisms and environments need to be clarified before appropriate and sustainable applications of nanoparticles can be established.
\end{abstract}

Key Words DNA damage, Genotoxicology, Nanoparticles, Nanotoxicology, Risk assessment

\section{INTRODUCTION}

Nanotoxicology is an emerging branch of toxicology that concerns about the detrimental health issues associated with nanoparticles (NPs) through nanotoxicological studies in biological organisms and the environment [1]. NPs may exert toxicity in several ways, e.g., by interacting with biological fluids or penetrating the central nervous system, leading to cardiac or cerebral dysfunction [2]. NPs may also interact with mediators to result in inflammatory response activation, release ions as breakdown products inducing cellular oxidative stress, or interact with genetic materials and eventually damage DNA, directly or indirectly [2]. These phenomena may lead to increased cancer risks. Of concern, the complex issues of NP-based toxicity may include genotoxicity, molec- ular determinants, physicochemical determinants, exposure routes, biodistribution and biotransformation, and regulations in different sectors.

NPs offer new opportunities for industrial, medical, and commercial products. Today, their utilization and global market become exponentially increasing [3]; however, it remains unclear how they affect biological organisms and a poor understanding of their biological effects may lead to unexpected, deleterious health consequences. Although the amount of research assessing the environmental impacts of NPs has increased over past decades, information on the environmental fate, transport, transformation, bioavailability, and relevant toxicity of a variety of nanomaterials is still uncertain. NPs may carry potential risks to human health and the environment through their bulk production, usage, and environmental

Received January 5, 2021, Revised June 8, 2021, Accepted June 16, 2021

Correspondence to Young Rok Seo, E-mail: seoyr@dongguk.edu, https://orcid.org/0000-0002-4093-4073

Check for updates

*These authors contributed equally to this work as co-first authors. 
release $[4,5]$. It is possible that certain levels of NPs could accumulate in environmental compartments, e.g., air, soil, and water, where they pose risks to biological organisms [6-9]. Attention has been also paid to their accumulation in oceanic and river sediments, as evidence that the accumulation of $\mathrm{ZnO}$ NPs was significantly higher in sediment than in urban soil and landfill [6].

Of a serious concern, genotoxicity is associated with NPs through the initiation and progression of genetic abnormalities including gene mutations, structural chromosomal aberrations, and recombination $[10,11]$. In this review, we discuss the genotoxicological concepts of NPs in different ecosystems, so called eco-genotoxicology, and address the roles of environmental processes and the fate of NPs. We also highlight the (geno)toxicological features of NPs in environmentally relevant organisms, key mechanisms of genotoxicity and the reliability of endpoint toxicity assays. Furthermore, the current challenges in NP genotoxicity research and recommendations are discussed to enhance the value of NP-based genotoxicity data.

\section{BENEFICIAL EFFECTS OF NANOPARTICLES}

Nanotechnology is an advanced field of science as a versatile technology, which is increasingly gained attention among researchers [12]. Regarding EU Commission's recommendations, NPs are referred as particles with ca. Regarding EU
Commission's recommendations, nanoparticles are referred as particles with approximately 1 to $1,000 \mathrm{~nm}$ size range wherein at least $50 \%$ in fraction has diameter of range 1 to $100 \mathrm{~nm}$ in at least one dimension [3]. In term of the specific surface area, they may be referred as particles with specific surface area by volume $>60 \mathrm{~m}^{2} / \mathrm{cm}^{3}$ [13].

Based on their origin, NPs are classified as natural or synthetic, besides their size, shape, chemical composition and surface characteristics. Natural NPs occur in the Earth's compartments (i.e., atmosphere throughout troposphere, biosphere including microorganisms, plants and humans, hydrosphere covering marine- and fresh-water system, and lithosphere including rocks, soils, magma or larva) via global biogeochemical cycle (e.g., biochemical weathering, photo-oxidation, redox and precipitation reactions, biomineralization, physical fragmentation, gas-solid nucleation in the atmosphere, etc.) $[14,15]$. The synthesis of artificial surfaces with nano-scaled templates and features with technological utilities becomes available from natural sources [16,17].

Regardless to human activities, synthetic NPs are also be generated by natural processes, for instance, micro- and nano-scaled plastics in water bodies and marine organisms are generated via weathering process $[18,19]$. Synthetic/engineered NPs are produced via different means, including mechanical grinding, byproducts as engine exhaust and smoke, or fabricated by physical (e.g., physical vapor deposition, formation of thin films), chemical (e.g., chemical vapor depo-

Table 1. Overview application of synthetic NPs in various fields including biomedical, environmental, agricultural, and industrial aspects

\begin{tabular}{ll}
\hline \multicolumn{1}{c}{ Utilization of NPs } & \multicolumn{1}{c}{ Description } \\
\hline Medical aspects & NPs can perturb microbial membrane and inhibit microbial pathogens. \\
Antimicrobial activity & NPs can prevent or block the multidrug-resistance and biofilm formation. \\
Antimicrobial drugs resistance & NPs disturb cellular function, resulting in denaturation and structural malformation. \\
Antiparasitic applications & NPs induce cellular apoptosis, anti-proliferation, anti-metastasis, and cytotoxicity. \\
Anticancer applications & Effects of NPs may be beneficial for the treatment of free radical-related physiological \\
Antioxidant applications & conditions. \\
& NPs have potential on degrading synthetic dyes, due to their high photocatalytic activity \\
Environmental aspects & and large surface area. \\
Clean-up of pollutant dyes & Metal NPs can act as colorimetric sensor of heavy metal elements, due to the adjustable \\
Heavy metal ion sensing & size and distance-dependent optical features. \\
Toxicant removal & Metal NPs have potential on degrading persistent contaminants, such as polycyclic \\
& aromatic hydrocarbons and pesticides. \\
Agriculture aspects & NP-based filters are effective in detoxification of organic pollutants such as endosulfan, \\
Detoxification of agrochemicals & malathion and chlorpyrifos from water. \\
Control of plant disease & NPs have potential on controlling plant pathogens in a relatively safer manner compared \\
Pesticides applications & NPs in pesticide formula refer as smart delivery system of water-soluble pesticide for its \\
Industrial aspects & slow release. \\
Catalytic activity & NPs enhance catalytic reaction rate by promoting the adsorption of reactants on their \\
& surface, thereby alleviating activation energy barriers.
\end{tabular}

NPs, nanoparticles. 
sition, chemical reduction), biological (e.g., biosynthesis of NPs by microorganisms) or combined methods [20-23]. NPs are widely applied in the variety of consumer products for daily purposes as well as innovative products and processes, due to their unique features with distinctiveness to their counterparts of bulk particles (Table 1) [3,11,21-23]. According to their origin, NPs exist naturally or can be produced intentionally. The latter type can be classified as follows [3].

1. Non-metallic inorganic NPs $\left(\mathrm{TiO}_{2}, \mathrm{SiO}_{2}, \mathrm{ZnO}, \mathrm{Fe}_{2} \mathrm{O}_{3}\right.$, $\mathrm{Fe}_{3} \mathrm{O}_{4}$ )

2. Metal NPs and alloys ( $\mathrm{Au}, \mathrm{Ag}, \mathrm{Cu}, \mathrm{Fe}, \mathrm{Ni}, \mathrm{Pt}, \mathrm{Pd}$ )

3. Carbon-based nanomaterials (fullerenes, carbon nanotubes, carbon nanofibers, graphene)

4. Organic nanopolymers and dendrimers (polymeric NPs, polymer nanotubes, nanowires and nanorods, nanocellulose)

5. Quantum dots (cadmium telluride, cadmium selenide)

6. Composite-based nanomaterials (e.g., hybrid nanofibers or complex structures like metalorganic frameworks). The composites may be any combinations of carbon-, metal-, or organic-based nanomaterials with any form of bulk materials.

\section{ECO-GENOTOXICOLOGY}

The Society of Toxicology defines toxicology as "the study of the adverse effects of chemical, physical and biological agents on human, animals and the environment". Eco-genotoxicology applies the principles and techniques of genetic toxicology to assess the effects of environmental toxicants, in the form of genotoxic agents, on the health of ecosystems [8]. A unique characteristic of nanotoxins is that materials that are rarely harmful in their bulk form may be toxic at the nanoscale. Figure 1 depicted transformation of NPs in environmental systems via physical, chemical or biological process and potential mechanisms underlying toxicity of the environmentally transformed NPs. From an environmental perspective, the potential toxicity and behavior of NPs not only depends on physicochemical factors (e.g., size and size distribution, shape, charge, coating, aggregation/agglomeration state) but also on the presence and biochemical compositions of co-pollutants (e.g., heavy metals, organic pollutants etc.) as well as interaction with biomolecules in living organisms (e.g., proteins) (Fig. 1). NPs commonly react with cells and biological components (e.g., DNA or proteins) and

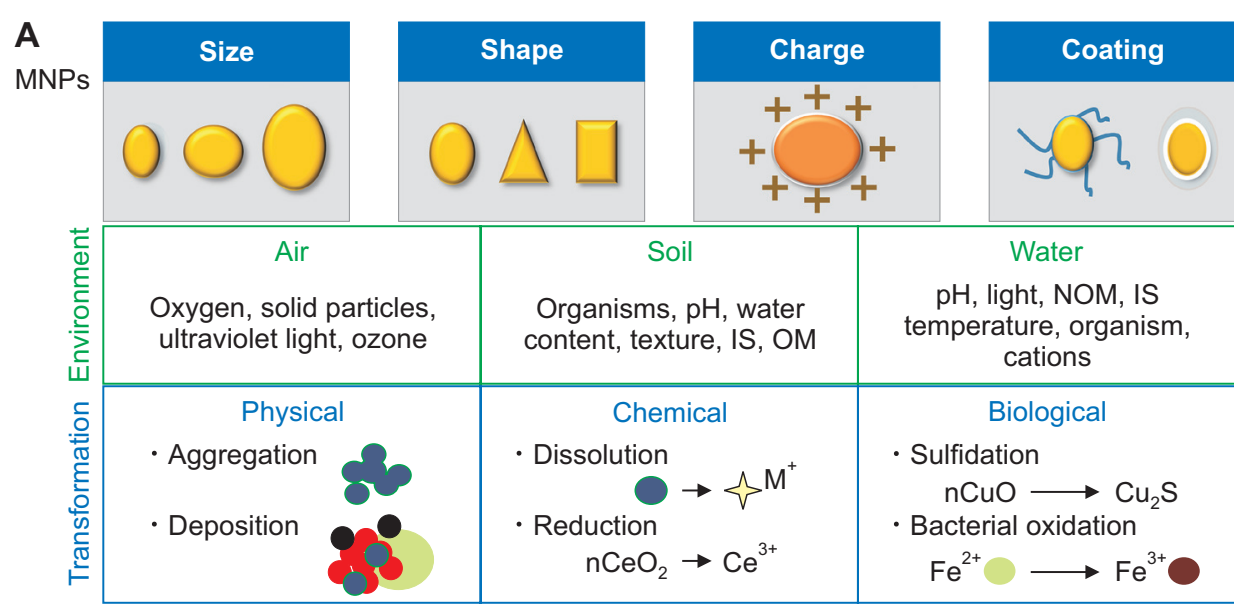

B

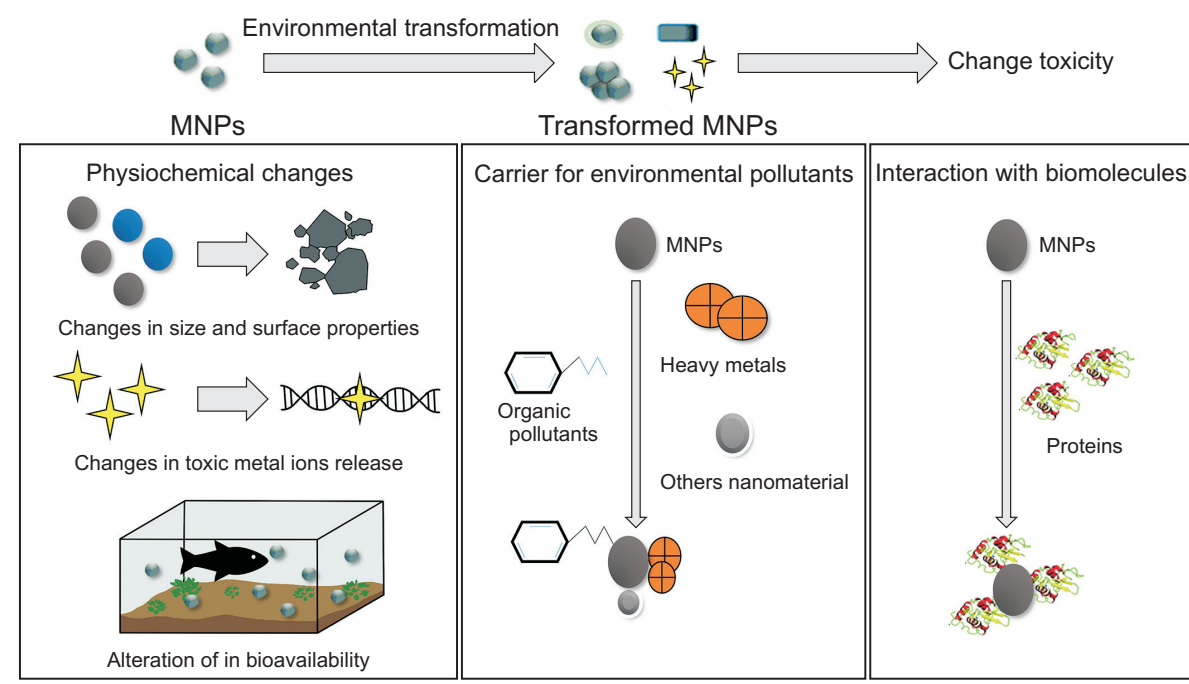

Figure 1. Schematic diagram illustrating (A) transformation of nanoparticles (NPs) in environmental systems and (B) key mechanisms underlying the toxicity of transformed NPs relative to pristine particles. NPs may encounter physical-, chemical-, or biologicalbased transformations in different environmental media, i.e., air, soil, and water. The physicochemical traits of NPs in combination with environmental features determines the transformation pathway. During the transformation process, NPs may interact with other co-pollutants and biomacromolecules, thereby resulting in the alteration of physicochemical traits, bioavailability, and differential toxic responses mediated by transformed versus pristine NPs. In an environmental viewpoint, the potential toxicity of transformed NPs not only relies on physicochemical traits (e.g., size and size distribution, charge, coating, aggregation/agglomeration state) but also on the presence of copollutants (e.g., heavy metals, organic pollutants etc.) as well as interaction with biomolecules in living organisms (e.g., proteins). MNPs, Magnetic nanoparticles; IS, lonic strength; OM, organic matter; NOM, natural organic matter. 
can travel through internal organelles as well as the bloodstream, and these characteristics may enhance their ability to enter various organs and activate inflammatory and stress responses [9]. For example, the inhalation of nano-scaled urban particulate matter appears to cause the pulmonary injury and inflammation that dysfunction regulatory system in the cardiovascular system, due to the induced oxidative stress (https://ec.europa.eu/health/). Moreover, NPs are known to exert oxidative stress, DNA damage, and cell cycle arrest in human cells [11]. The mechanisms of NP toxicity, however, remain unclear. DNA damage caused by NPs is relevant to both humans and other species in the environment. The exposure of pregnant women to genotoxic NPs may induce carcinogenesis or genetic abnormalities in fetuses, and abnormalities in humans highlight their genotoxic potential to other species [11].

It is noteworthy that species in the environment are likely to be continuously exposed to higher levels of NPs than humans, especially via the contamination of waterways by industrial manufacturing sites. The monitoring of key environmental species for genotoxic markers and assessing the detrimental effects of NPs are crucial to protect wildlife from extinction in extreme cases. The overall toxicity of NPs to species in the environment is currently limited [24]; however, NP-induced DNA damage may cause heritable abnormalities and alter the fitness of species (Fig. 2) $[8,9,25]$. Monitoring species for NPs-induced (geno)toxicity would provide insights into the potential threats posed by NPs to human health. Therefore, studying genetic interference in "sentinel species" would address how exposure to NPs may affect humans.

The number of toxicological studies involving wild species is accumulating, but NP genotoxicity is not well understood in these species. For instance, the toxicological effect of $\mathrm{TiO}_{2}$ NPs and quantum dot (QD) in vitro were investigated in fish cells and whole mussels, respectively $[13,14,26]$. Using the in vitro comet assay, researchers found that $\mathrm{TiO}_{2}-\mathrm{NPs}$ exerted some degree of DNA damage (at doses of 1, 10, and 100 $\mu \mathrm{g} / \mathrm{mL}$ ) after treatment with UV-A irradiation, implying that photo-genotoxicity has a significant impact on fish cells [27]. The genotoxicity in these fish cells was only observed in the presence of formamidopyrimidine DNA glycosylase, an enzyme that cleaves oxidatively damaged DNA. In the absence of formamidopyrimidine DNA glycosylase, only the highest concentration of $\mathrm{TiO}_{2}$-NPs exhibited a positive result. These findings demonstrate that the $\mathrm{TiO}_{2}$-NPs mediated genotoxicity indirectly through reactive oxygen species (ROS) intermediates. However, the DNA damage was not detected with the micronucleus (MN) assay $[27,28]$. In the other in vivo study, mussels treated with cadmium telluride showed increased ROS levels but less DNA damage relative to the untreated group, suggesting that cadmium telluride protects the cells in the gills, digestive glands, and gonads from endogenous intracellular DNA damage [26]. Further studies are, however, necessary to confirm these findings.

Given the potential exposure routes and contamination of the waterways by manufacturing plants, it is crucial to assess the effects of NPs on the genetic components of aquatic species (freshwater and seawater). As with studies in mammalian cells, current studies on wild species suffer from a lack of thorough particle characterization. In vivo studies are more complicated because of the confounding factors affecting both biodistribution and bioaccumulation in the target tissue.

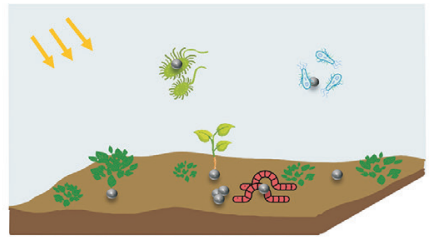

1. Toxicity to airborne and soil organisms

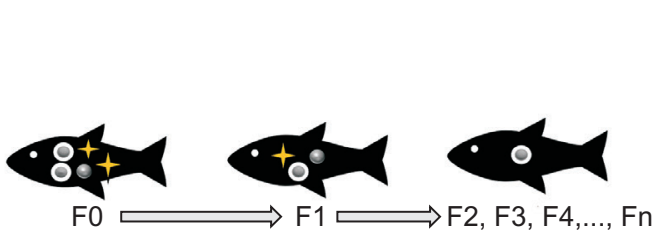

3. Developmental and heredity toxicity

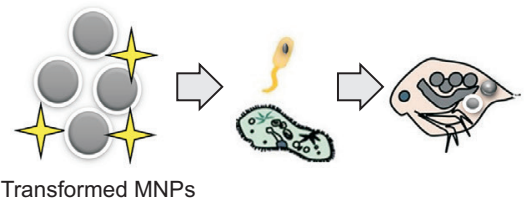

2. Toxicity to aquatic organisms

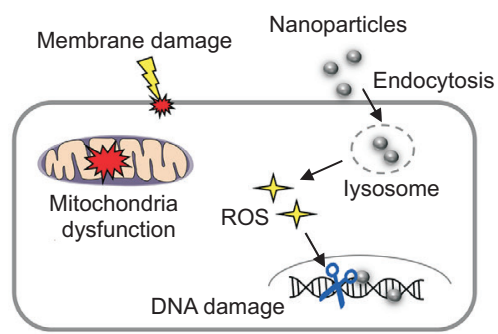

4. In vivo toxicity

Figure 2. A scheme representing the potential toxicological effects of nanoparticles (NPs) after environmental transformation. Environmentally transformed NPs may induce ecotoxicity in terms of cellular, molecular, developmental, or heredity toxicity in airborne, soil, and aquatic organisms. The deleterious molecular effects mediated by the transformed NPs, including membrane shrinkage, mitochondria dysfunction, lysosomal interference, and DNA damage, may differ from those mediated by pristine particles. MNPs, Magnetic nanoparticles; ROS, reactive oxygen species. 
Indeed, monitoring the levels of internal NPs reaching the tissues and cells and correlating these with the degree of toxicity, including genotoxicity, holds promise for precise risk assessments in vivo and the development of more eco-friendly and safe NPs.

\section{ENVIRONMENTAL FATE AND BEHAVIOR OF NANOPARTICLES WITH ECOGENOTOXICOLOGICAL RELEVANCE}

The potential routes by which NPs enter the environment include manufacturing, product incorporation, and recycling or waste disposal [29]. The toxicological properties of NPs not only depend on their intrinsic physicochemical features but also on their interactions with biological components and the composition of chemicals in the environment.

\section{Air and aerial ecosystems}

There are known to be natural background levels of NPs in the atmosphere. Generally, natural air-borne NPs are found at low levels relative to the potential levels engineered NPs released from anthropogenic activities may reach $[30,31]$. Pristine NPs themselves have short residence times, whilst accumulation mode particles can persist in the atmosphere [30]. NPs-containing diesel are potentially released into the atmosphere; these NPs contribute to global warming because of their light-absorbing ability and may harm human health [30]. In the atmosphere, so-called primary particles are NPs directly released from a pollution source [32]. Volatile NPs, namely secondary NPs, consist of nucleation mode particles generated by photochemical processes [32]. Key atmospheric toxicants include sulfuric acid, nitric acid, and organic gases [32,33], and key factors, e.g., temperature, residence time, dilution ratio, and concentration of carbon particles, determine the formation of secondary airborne NPs [34-37]. Therefore, environmental processes may play key roles in raising particle concentrations in the atmosphere above natural background levels. In addition, nucleation particles may continuously grow via vapor condensation and coagulation, leading to optical atmospheric effects, the soiling of buildings, and climate change [31,32,38,39].

Ag NPs at concentrations over $30 \mu \mathrm{g} \mathrm{mL}-1$ were found to suppress the growth of airborne Staphylococcus isolates [40]. Other report has also indicated that the toxicity of Ag NPs in organisms may be changed after their transformation in the air compartments. Moreover, the transformation of $\mathrm{ZnO}$ and $\mathrm{TiO}_{2}$ NPs in PM2.5 airborne particulate matter enhanced toxicity in Gram-negative and Gram-positive bacteria [41].

\section{Soil and terrestrial ecosystems}

Soil and sediments can act as NP reservoirs. Through direct or indirect release (e.g., via wastewater treatment plants, aerial deposition, or waste disposal), NPs can be deposited in soil or aquatic sediment where they represent a significant environmental exposure risk. Soil is a pollutant sink, which is of particular concern because of the entry of NPs into food webs and the consumption of contaminated agriculture by humans [42].

In terrestrial ecosystems, natural NPs exist in soil colloids, e.g., organic matter, clays, iron oxides, and other minerals, which play key roles in biogeochemical cycling. Therefore, the introduction of engineered NPs into soil ecosystems may alter the natural NP profile and interfere with soil development or species behavior $[30,43]$. The terrestrial fate of NPs is an issue of complexity, and data on the transport of NPs through soils is scarce. The unique characteristics of NPs relative to their bulk and macroscopic material may influence their fate and effects on the terrestrial environment $[30,44,45]$. NPs' large surface-area-to-volume ratio, reactivity, small size, aggregation, and absorbance are the main factors determining their degree of adhesion to soil and, therefore, their mobility and transport [46]. The bioavailability of NPs is dependent on their specific features, as well as the soil composition, porosity, hydraulic conductivity, groundwater gradient and flow velocity, and geochemical properties (e.g., dissolved oxygen; $\mathrm{pH}$; ionic strength; and concentrations of nitrate, nitrite, and sulfate) $[31,30,47]$. A previous study showed that Au-NPs reduced absorption, biodistribution through tissues, and reproduction in the earthworm Eisenia fetida, emphasizing the importance of food chain accumulation and trophic transfer. However, information on the bioaccumulation of NPs in higher-level organisms is lacking [48].

NPs are widely utilized as antimicrobial agents against pathogenic bacteria, but their abuse may deplete populations of beneficial soil microorganisms, such as plant growth promoters, element cycling modulators, and pollutant detoxifiers. The NPs Ag, CuO, and $\mathrm{ZnO}$ are toxic both to pathogenic bacteria like Escherichia coli and Staphylococcus aureus and beneficial microorganisms such as the bio-remediator and root colonizer Pseudomonas putida [49,50]. These NPs exhibited higher toxicities compared with their equivalent bulk materials [51,52]. Therefore, the larger the sink and more reactive the NP in terrestrial systems, the more research and standard testing protocols are required to validate their fate, behavior, and food-chain bioaccumulation.

It has reported that NPs could exert toxicity to terrestrial plants, such as inhibition of seed germination, retardation of plant growth, and perturbance of mineral nutrition and photosynthesis [53,54]. $\mathrm{CeO}_{2}$ and $\mathrm{ZnO}$ NPs could remarkably decrease the corn productivity and quality [55]. The potential toxicity of NPs in plant usually relies on their intrinsic features. $\mathrm{Fe}_{3} \mathrm{O}_{4} \mathrm{NPs}$ promoted the root growth of tomato plants, whereas $\mathrm{SnO}_{2} \mathrm{NPs}$ retarded their root growth [56]. Furthermore, the toxicity of NPs to terrestrial organisms could be changed after their transformation in soil matrices. For instance, transformed $\mathrm{NP} \mathrm{TiO}_{2}$ could induce the apoptosis in various tissues of the earthworm Lumbricus terrestris [57]. Not only the terrestrial organisms, the environmental transformation also 
influence the toxicity of NPs to terrestrial plants [55]. It has reported that ZnO NPs at the concentrations of 400 and 800 $\mathrm{mg} \mathrm{kg}$-1decreased the biomass of roots and shoots in corn plants (Zea mays) [58]. Intriguingly, decrease in biomass was undetectable in plants treated with the same concentrations of ZnO NPs after addition of alginate [58]. Indeed, environmental transformation can affect the bioaccumulation and biodistribution of NPs in terrestrial plants. Levels of silver in alfalfa roots and shoots treated with Ag NPs were relatively higher than in plant treated with Ag nanoparticles were relatively higher than in plant treated with $\mathrm{Ag}$ sulfide as transformed Ag NPs [59]. The majority of Ag NPs accumulated in the border cells and elongation zone of the roots, whereas the transformed Ag sulfide NPs still attached to the root exterior. These selective bioaccumulation and biodistribution between pristine and transformed NPs may contribute to the difference in their phytotoxicity [60].

\section{Water and aquatic ecosystems}

NP-containing waste products may be released into aquatic systems, increasing the possibility of NP contamination [30]; however, there is presently little information available on the behavior and fate of NPs in aquatic systems. In addition to biological substances such as bacteria, colloid particles (1 $\mathrm{nm}$ to $1 \mu \mathrm{m}$ in size), which are macromolecules and molecular assemblies, include organic, e.g., humic substances and fibrillar material, protein, and polysaccharide, exudates from microorganisms, and inorganic matter, such as Fe, Mn, $\mathrm{Al}$, and Si oxides, and thus are analogous to manufactured metal oxide NPs $[29,30]$. Colloidal fate and behavior are affected by aggregation processes. Colloids tend to form aggregations (> $1 \mu \mathrm{m}$ in size), and their transport depends on their organic composition, being denominated sedimentation. Similar to metals, engineered NPs tend to aggregate and are subsequently deposited, which has positive impacts on water body decontamination, as the transfer of NPs from the water column to sediments leads to pollutant loss. Notably, NPs may bind to natural colloids and consequently influence their behavior, thereby complicating the elucidation of their impact on aquatic systems. Characterizing NPs' size, surface charges, and chemical reactivity enables us to predict their key biological effects in aqueous environments, including ROS formation, phototoxicity and photocatalytic activities, and interaction with soluble pollutants [61]. However, these physicochemical traits are difficult to predict because of the complexity of aquatic systems.

In oceans, changes in physicochemical characteristics, such as temperature, that may affect aggregation and colloid chemistry are related to depth. Similar to the behavior of NPs in freshwater, NPs in the ocean may aggregate and settle to the bottom, as well as accumulate at the interface between cold and warm currents or be transformed by biota. The particles may therefore present a considerable threat to both pelagic species, who feed in midwater zones, and benthic spe- cies in the sediment. In addition, NPs can exist on the surface microlayers of the oceans, leading to the risk of aerosol exposure to marine birds and mammals as well as to organisms habituating on the surface microlayer $[62,63]$. In a previous study, researchers reported fullerenes C60-based toxicity in the freshwater crustacean Daphnia magna, the marine copepod Hyalella Azteca, and fish such as Pimephales promelas and Oryzias latipes [64]. Previous findings also showed that toxicity increased with increasing salinity, and there was higher particle aggregation in the eggs of Japanese medaka treated with fluorescent NPs (30 mg/L) at various salinities. At salinities relevant to normal seawater, the accumulation of NPs was reduced, whereas egg mortality was still high [65]. Given these results, predicting the effect of NPs on aquatic systems is complicated; however, ecotoxicological studies have demonstrated that aquatic organisms, both unicellular and multicellular, are likely to be impacted by NPs $[31,47,66]$.

Contamination of the aquatic environment is caused by runoff sources, such as wastewater treatment facilities, manufacturing processes, and transportation. The NPs may sequester in the aquatic medium and transfer to higher trophic levels via algae and filter feeders. NPs may aggregate in the aquatic environment and sediments, threatening benthic and higher trophic organisms via their direct and/or indirect uptake. NPs can enter via the epithelia of the gut and hepatopancreas in invertebrates or via the gills and epithelia of fish [67].

Biocidal agents, including Ag-NPs, are known to be released from biocidal plastics, textiles, paints, and other household products [68-70], mainly via industrial wastewater plants, eventually reaching the aquatic environment [70]. A published report of the annual estimates of silver residues from Europe, Asia, and North America shows that 190 to 410 tons and $11.5 \%$ to $31.7 \%$ of residues treated in wastewater plants were found in natural water sources [71]. Although Ag-NPs undergo wastewater treatment before discharge, a significant amount (ca. 10\%) is released in effluent [72]. The typical concentration of Ag-NPs in surface water is uncertain, as estimates range from $0.09-2.63 \mathrm{ng} / \mathrm{L}$ [73] to $40-320 \mathrm{ng} / \mathrm{L}$ [72]. A recent study revealed the fate, bioavailability, and toxicological effects on fish of Ag-NPs from municipal effluents [74].

It has reported that NPs exert toxicity to aquatic organisms typically covering microbes, algae and plants, invertebrates and vertebrates [75]. In particular, toxicological effects of NPs on microbial and algal communities could be determined by perturbing the community compositions, diversities or activities and the biomass content [76]. In presence of $\mathrm{ZnO}$ or combined $\mathrm{ZnO}-\mathrm{TiO}_{2} \mathrm{NPs}$, the genus distribution and composition of the microbial community appeared to be shifted in river water bodies [77]. In bacteria and algae, metal NPs-mediated toxicity could be measured in terms of viability, growth, and morphological disturbances as well as increase in ROS [78-80]. Basically, toxicological effects of metal NPs were 
investigated in zebrafish, a vertebrate model for nanotoxicology research, including general toxicity (e.g., mortality, hatch rate-time, body length etc.), physiological changes (e.g., pericardial edema, yolk sac swelling, axial malformations, eye development and pigmentation dysfunction etc.) and aberrant behavior (e.g., basal swimming rate and rest/wake cycle etc.) [15,81-84].

\section{MECHANISIMS OF NANOPARTICLE- INDUCED GENOTOXICITY}

Current reviews on NP-based genotoxicity are available elsewhere [11,74,85-88]; here, we briefly highlight the key mechanisms relevant to nano-genotoxicity. Genotoxicity is classified into primary and secondary forms (Table 2 and Fig. 3). The former primarily results from the direct interaction of NPs with genetic components via the toxicological action of particulates or dissolved forms on the nucleus. Direct DNA interactions can also occur during mitosis because of the breakdown of the nuclear membrane. In addition, primary genotoxicity may occur without physical interactions between DNA and NPs, specifically in the interference of proteins crucial for DNA replication, transcription, or repair (i.e., indirect DNA damage). Secondary genotoxicity can arise from the chronic in vivo inflammation mediated by macrophage and neutrophil cells, resulting in the excessive formation of ROS. To date, only primary genotoxicity has been found in aquatic organisms [89]. An in vitro screening assay for genotoxic potential (e.g., DNA strand breaks and mutagenicity endpoints) followed by an in vitro cytogenetic assay is an approach used in the genotoxicity assessment of aquatic organisms. Non-genotoxicity should be considered when both assays give negative results, but an in vivo test would be further warranted when at least one of the assays is positive [90]. For reliable results, dynamic in vivo tests are preferable over static in vitro tests.

There are a number of direct and indirect mechanisms/ pathways that can induce DNA damage by NPs (Fig. 3). If the NPs penetrate into the nucleus, then physical interaction between the particles and the DNA molecules or DNA-related proteins (e.g., intranuclear protein, histone proteins, etc.) may

Table 2. Summary of key genotoxic mechanisms of the nanoparticles in terms of their molecular interaction and cellular processes

\begin{tabular}{lll}
\hline \multicolumn{1}{c}{ Primary direct } & \multicolumn{1}{c}{ Primary indirect } & \multicolumn{1}{c}{ Secondary genotoxicity } \\
\hline Effect on DNA & Effect on nuclear proteins & Excessive ROS accumulation by inflammatory cells \\
Structure/Integrity & Centrioles & \\
Replication & & \\
Transcription & Effect on chromosomal proteins & Oxidative DNA damage via accumulative ROS levels \\
Effect on chromosome & Cell cycle check points & \\
Clastogenic & & \\
Aneugenic & Effect on relevant cellular processes & \\
& Replication & \\
& Transcription & \\
& RNA repair proteins & \\
& ROS production & \\
\end{tabular}

NPs, nanoparticles; ROS, reactive oxygen species.
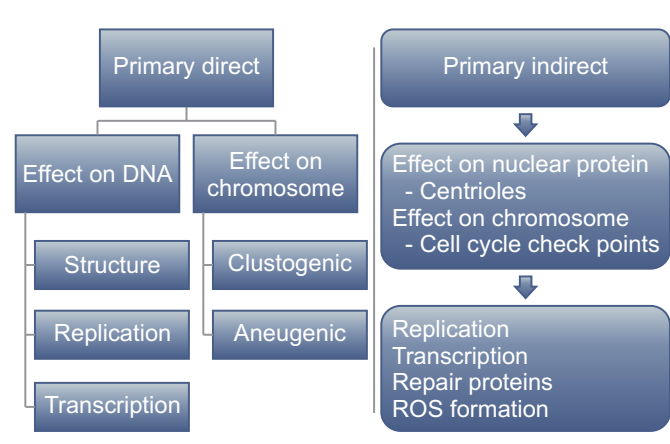

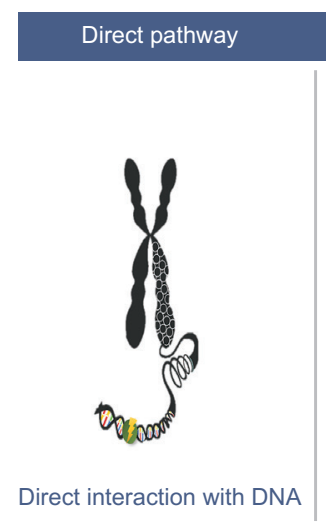

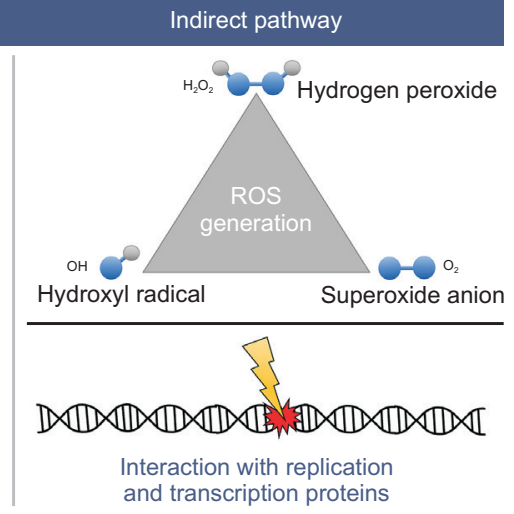

Figure 3. A schematic overview indicating main genotoxicity pathways of nanoparticles. The direct pathway of nanoparticle-induced genotoxicity is mediated by the physical interaction of nanoparticles with genetic components, whilst the indirect pathway is based on the induction of ROS (e.g., hydroxyl, peroxide, and superoxide radicals) and perturbance of replication- and transcription-related proteins. ROS, reactive oxygen species. 
directly lead to structural instability to the genetic material $[91,92]$. DNA damage may also occur via indirect pathways where the NPs do not physically bind to the DNA molecules, but with other cellular proteins (e.g., replication and transcription proteins related in the cell division). Additionally, they may trigger other cellular responses that indirectly result in genotoxicity, such as inducing oxidative stress, inflammation and aberrant signaling responses [93,94].

Taken together, NP-mediated biological effects, from molecular [95-98] and subcellular [86,99,100] levels to organism $[101,102]$ and population effects [103], appear to be determined by several complex factors. These factors may be divided into (i) the intrinsic physicochemical features of NPs $[99,100,104,105]$, (ii) the presence of other co-pollutants in the environment [106-108], and (iii) extrinsic characteristics (e.g., ROS inducing capacity and dissolution) [109]. The physicochemistry of the aqueous media, e.g., dissolved oxygen content, hardness, $\mathrm{pH}$, ionic strength, and natural organic matter, is also known to affect the toxicity of NPs $[80,110$ 120].

\section{METHODS FOR ASSESSING NANOPARTICLE-MEDIATED GENOTOXICITY}

To evaluate nano-genotoxicity, DNA strand breaks and mutagenicity endpoints are widely detected using comet, Ames, chromosome aberrations, and MN assays. Gene expression is determined using the random amplified polymorphism DNA PCR technique, DNA microarrays, and real-time PCR [86,121-123]. Reviews on various genotoxicity assays recommend that the comet assay is used because of its high detection sensitivity and the very low volume of sample required. To assess chromosomal damage, the MN assay is typically preferable over the chromosome aberration assay [124,125]. The Ames test is commonly employed in toxicological assessments of conventional chemicals but is recognized as the least-favored NP assay as a result of the insignificant differences in mutagenicity assigned to different NP types, such as $\mathrm{CuO}-\mathrm{NP}, \mathrm{TiO}_{2}-\mathrm{NP}$, and Ag-NP [126-129], and its genotoxic insensitivity relative to the comet or MN assays [130132]. H2AX phosphorylation and 8-hydroxy-deoxyguanosine assays may be used as complementary methods to gain mechanistic insights into nanoparticle-induced genotoxicity. Henceforth, we focus only on the preferable comet and MN assays for assessing nanoparticle-based genotoxicity.

\section{The comet assay}

The comet assay is a versatile technique for assessing single and double-stranded DNA breaks in individual cells, both in vitro and in vivo [133,134]. It facilitates the measurement of alkali-labile sites, oxidative DNA damage, DNA-DNA or DNA-protein cross-links, and abasic sites $[135,136]$ and is useful for evaluating DNA repair capability after toxicant removal [137]. However, its application may be limited for NPs because of their prolonged intracellular accumulation and toxicological persistence to DNA [138].

The comet assay has a broad application, from evaluating the genotoxic potential of novel substances [138], monitoring environmental toxicants [139-143], and assessing DNA repair capacity or DNA damage recovery $[140,144]$ to measuring the genotoxicity of NPs in mammalian and non-mammalian systems [145]. Detailed information on the comet assay has been elucidated elsewhere [11,137-139,146], and recent studies have demonstrated the utility of the comet assay for estimating the genotoxic potential of NPs in aquatic organisms, e.g., algal species [94,147].

\section{The MN assay}

The MN assay is capable of detecting chromosomal damage and loss in binucleated cells [86] and confers potential advantages in the genotoxic assessment of conventional chemicals in environmental systems [148]. Micronuclei may contain aneugenic (whole genome) or clastogenic (chromosome breakage) damaged material [149]. During the MN assay procedure, cells are incubated with cytochalasin $B$, an inhibitor of actin polymerization involved in constricting the cytoplasm between the daughter nuclei during cytokinesis via microfilament ring formation [148]. As a result of blocking cell division with cytochalasin B, binucleated cells are formed, through which micronuclei are quantified. Cytochalasin B also blocks endocytosis and, thus, may inhibit the uptake of NPs. The preincubation of cells with NPs followed by the addition of cytochalasin B is recommended to overcome this challenge [125]. Moreover, Organization for Economic Cooperation and Development (OECD) guidelines on the MN assay suggest removing the test substance(s) prior to the addition of cytochalasin B.

Unlike conventional chemicals, the complete removal of NPs from cells after exposure is very difficult [150], which restricts the usefulness of the MN assay in the nano-ecotoxicological field. Confounding factors influencing genotoxicity assessments include the use of actin inhibitors and the addition of fetal bovine serum in the cell culture medium [151].

\section{THE CURRENT SITUATION}

Although accumulating evidence indicates that some NPs exert genotoxic potential, there are inconsistent scientific findings, probably due to the various confounding factors, and it is therefore difficult to draw firm conclusions. For instance, there may be inconsistencies in the dose metrics of tests and conversion factors used to equate units of dose, which are important for making comparisons among studies $[31,32,130,150]$. In addition, the physicochemical characterization of NPs, in terms of their pristine and environmentally transformed forms, has been neglected in several studies $[126,127]$.

Another important issue of study variability is the selection 
of appropriate test systems. It is problematic when only single genotoxicity tests are applied, since various tests contribute to different endpoints depending on the test substance's mechanism of toxicity. For instance, the MN assay determines the clastogenic and aneugenic potential of toxins to lead to chromosome fragmentation or loss of whole chromosomes [148], respectively, and for these to become enclosed within a MN rather than the daughter nuclei. Indeed, the comet assay assesses un-repaired DNA strand breaks and alkali-labile sites but may exclude early apoptotic and necrotic cells containing fragmented DNA, namely hedgehogs [152]. Usually, the comet assay displays higher degrees of damage relative to the MN assay because it also detects DNA breaks that are repairable and evaluates the post-DNA-damage repair capacity. Although the degree of damage assessed by the $\mathrm{MN}$ assay remains after cell division, the technique gains more information on un-repairable errors, providing stronger evidence in the genotoxicity assessment [152].

Regarding genotoxic effects, the controversial results of some studies identified the same NP effects using different testing assays. For instance, both the comet and MN assays indicated that $\mathrm{TiO}_{2}-\mathrm{NPs}$ induced DNA damage, while the Ames mutagenicity test and chromosome aberration assay led to negative results $[134,154]$. Moreover, differential results between the MN and the comet assay are mentioned within the same report [155]. When assessing genotoxic potential, it is obvious that using a single genotoxicity assay is inadequate to draw strong conclusions, as no single test can cover all the potential forms of DNA damage induced by NPs. The established standard regulatory guidelines for measuring the genotoxicity of a test substance recommends the use of a battery of tests assessing a range of various endpoints, through which useful information on their mechanisms of toxicity can be gained. This is also essential for obtaining a comprehensive view of how NPs interact with cellular components.

Any issues about the use of surfactants to disperse NPs should take into account $[130,150]$. This raises the question if forced dispersion using a surfactant indeed represents physiologically relevant exposure conditions or if natural surfactants (e.g., biological fluid in lungs) actually interact with NPs. Nevertheless, this would depend on the exposure route. Not only can the use of surfactants cause a false exposure situation but it also carries the risk of intrinsic toxicity leading to a false-positive response. Hence, using surfactants is another complex issue that may confound the outcomes.

Another source of study variability is the cell line used in in vitro studies. In mammalian studies, cancer cell lines are usually the experimental models of choice, but their responses depend on their genetic background and stability. For instance, normal mesothelial cells were more sensitive to DNA damage on single-walled carbon nanotube exposure than malignant mesothelial cells [156]. To determine the genotoxicity of NPs, the selection of a test model with suitable stability and representative genetic background is crucial to avoid false-positive or -negative results. For germ cells, information regarding the genotoxic effects of NPs is very limited. However, a previous report indicated that $\mathrm{ZnO}$ and $\mathrm{TiO}_{2} \mathrm{NPs}$ dose-dependently increased DNA damage in human sperm cells [157]. Previous in vivo studies consistently demonstrated NP accumulation in the testes after exposure [158,159]. Therefore, DNA damage in germ cells might have detrimental effects on fertility, whilst heritable genetic interferences could lead to developmental impairments in offspring. With environmental health issues, it is also important to select both appropriate in vitro and in vivo test models that can reflect the potential exposure routes in an environmentally relevant scenario.

In addition to the aforementioned confounding factors, the most appropriate exposure duration for in vitro tests also needs to be optimized. In conventional genotoxicity assays, exposure periods of no more than 24 hours are used because chemical substances usually diffuse into the cells and the duration of their activity is restricted by their half-life. Therefore, prolonged exposures are unnecessary. It is apparent that the uptake and movement of NPs through cells is slower than chemical diffusion. Moreover, these NPs probably linger in the cells during mitosis, where they may interact directly with DNA when the nuclear membrane breaks down or with the mitotic machinery components, thereby leading to disrupted chromosomal segregation. Therefore, experimental exposure periods should be optimized within genotoxicity test systems. For instance, enhanced particle uptake with prolonged exposure duration was seen in a previous study that found 2-fold higher cobalt NP uptake after 48 hours of exposure compared with uptake after 24 hours [160]. Another relevant issue that requires clarification is the long-term intracellular fate of NPs. It is possible that a metal NP may not exert intrinsic genotoxicity but, after being inside a cell over a certain period, they may corrode to release metal ions, resulting in genotoxicity. With regards to the surface functionalization of NPs, the stability of surface coatings during exposure should be determined to avoid false-negative results, as genotoxic responses may occur from the extrinsic breakdown products.

\section{CONCLUSION}

The current information on the genotoxicity of NPs and their possible long-term impacts on human and environmental health and safety is still limited. A number of studies have focused on the cytotoxicity of NPs with respect to their unique physicochemical properties. Additionally, attention has been given to their cytotoxicity, genotoxic potential, the underlying mechanisms, and the key factors influencing their cellular uptake, retention, and biotransformation. The accumulating evidence indicates that many NPs possess DNA damaging activity; however, the conclusions are still controversial. A concerted attempt by scientific experts is required to draw 
comprehensive and firm conclusions. Recent reviews have mentioned important issues surrounding adequate NP physicochemical characterization, the selection of appropriate standard testing protocols, and correlation analysis of in vitro and in vivo results [130,161].

Therefore, we provide further recommendations for conducting more stringent and relevant nanotoxicological investigations: (i) clear details of the fabrication processes; (ii) the inclusion of suitable positive and negative controls when investigating if (geno)toxicological responses are consequences of NP interactions, surface functionalization, impurities, or breakdown products released during incubation; (iii) consideration of the long-term fates of NPs, and the effects of prolonged exposure over 24 hours within in vitro tests or any modified experimental conditions if appropriate; (iv) the use of a panel of genotoxicity tests with various endpoints to gain insight into toxicity mechanism; (v) genotoxicity assessments of NPs in germ cells, as well as somatic cells.

\section{ACKNOWLEDGMENTS}

This study was supported by a grant from Mahidol University, Thailand and also supported by Korea Environment Industry \& Technology Institute (KEITI) through The Chemical Accident Prevention Technology Development Program, funded by Korea Ministry of Environment (MOE) (2017001970001).

\section{CONFLICTS OF INTEREST}

No potential conflicts of interest were disclosed.

\section{ORCID}

Preeyaporn Koedrith, https://orcid.org/0000-0003-0160-6904 Md. Mujibur Rahman, https://orcid.org/0000-0002-6951-6270 Yu Jin Jang, https://orcid.org/0000-0002-8643-2722 Dong Yeop Shin, https://orcid.org/0000-0003-1575-3614 Young Rok Seo, https://orcid.org/0000-0002-4093-4073

\section{REFERENCES}

1. Guadagnini R, Moreau K, Hussain S, Marano F, Boland S. Toxicity evaluation of engineered nanoparticles for medical applications using pulmonary epithelial cells. Nanotoxicology 2015;9 Suppl 1:25-32.

2. Donaldson K, Tran CL. An introduction to the short-term toxicology of respirable industrial fibres. Mutat Res 2004;553:59.

3. Future Markets. Nanomaterials, the global market, forecast from 2010 to 2025. https://www.futuremarketsinc.com/the-globalmarket-for-nanomaterials-2010-2022/. Accessed January 15, 2021.

4. Sun TY, Mitrano DM, Bornhöft NA, Scheringer M, Hungerbühler $\mathrm{K}$, Nowack $\mathrm{B}$. Envisioning nano release dynamics in a changing world: using dynamic probabilistic modeling to assess future environmental emissions of engineered nanomaterials. Environ Sci Technol 2017;51:2854-63.

5. Amde M, Liu JF, Tan ZQ, Bekana D. Transformation and bioavailability of metal oxide nanoparticles in aquatic and terrestrial environments. A review. Environ Pollut 2017;230:25067.

6. Sun TY, Bornhöft NA, Hungerbühler K, Nowack B. Dynamic probabilistic modeling of environmental emissions of engineered nanomaterials. Environ Sci Technol 2016;50:4701-11.

7. Baker TJ, Tyler CR, Galloway TS. Impacts of metal and metal oxide nanoparticles on marine organisms. Environ Pollut 2014;186:257-71.

8. Shugart L, Theodorakis C. Environmental genotoxicity: probing the underlying mechanisms. Environ Health Perspect 1994;102(Suppl 12):13-7.

9. Kleinjans JC, van Schooten FJ. Ecogenotoxicology: the evolving field. Environ Toxicol Pharmacol 2002;11:173-9.

10. Oberdörster G. Safety assessment for nanotechnology and nanomedicine: concepts of nanotoxicology. J Intern Med 2010;267:89-105.

11. Singh N, Manshian B, Jenkins GJ, Griffiths SM, Williams PM, Maffeis TG, et al. NanoGenotoxicology: the DNA damaging potential of engineered nanomaterials. Biomaterials 2009;30:3891-914.

12. Porter AL, Youtie J. How interdisciplinary is nanotechnology? J Nanopart Res 2009;11:1023-41.

13. Commission recommendation of 18 October 2011 on the definition of nanomaterial. https://eur-lex.europa.eu/LexUriServ/ LexUriServ.do?uri=OJ:L:2011:275:0038:0040:en:PDF. Accessed January 13, 2021.

14. Baalousha M, Lead JR, Ju-Nam Y. Natural colloids and manufactured nanoparticles in aquatic and terrestrial systems. Treatise Water Sci 2011;3:89-129.

15. Sharma VK, Filip J, Zboril R, Varma RS. Natural inorganic nanoparticles--formation, fate, and toxicity in the environment. Chem Soc Rev 2015;44:8410-23.

16. Kokura S, Handa O, Takagi T, Ishikawa T, Naito Y, Yoshikawa T. Silver nanoparticles as a safe preservative for use in cosmetics. Nanomedicine 2010;6:570-4.

17. Davies JC. Oversight of next generation nanotechnology. Washington, DC, Woodrow Wilson International Center for Scholars, Project on Emerging Nanotechnologies, 2009.

18. A GK, K A, M H, K S, G D. Review on plastic wastes in marine environment- biodegradation and biotechnological solutions. Mar Pollut Bull 2020;150:110733.

19. Kögel T, Bjorøy $\varnothing$, Toto B, Bienfait AM, Sanden M. Micro- and nanoplastic toxicity on aquatic life: determining factors. Sci Total Environ 2020;709:136050.

20. Remédios C, Rosário F, Bastos V. Environmental nanoparticles interactions with plants: morphological, physiological, and genotoxic aspects. J Bot 2012;2012:751686.

21. Dauthal P, Mukhopadhyay M. Noble metal nanoparticles: plantmediated synthesis, mechanistic aspects of synthesis, and 
applications. Ind Eng Chem Res 2016;55:9557-77.

22. Wigginton NS, Haus KL, Hochella MF Jr. Aquatic environmental nanoparticles. J Environ Monit 2007;9:1306-16.

23. Prasad R, Kumar V, Prasad KS. Nanotechnology in sustainable agriculture: present concerns and future aspects. Afr J Biotechnol 2014;13:705-13.

24. Baun A, Hartmann NB, Grieger K, Kusk KO. Ecotoxicity of engineered nanoparticles to aquatic invertebrates: a brief review and recommendations for future toxicity testing. Ecotoxicology 2008;17:387-95.

25. Royal Society and Royal Academy of Engineering. Nanoscience and nanotechnologies: opportunities and uncertainties. https://royalsociety.org/ /media/royal_society_content/policy/ publications/2004/9693.pdf. Accessed September 12, 2020.

26. Gagné F, Auclair J, Turcotte P, Fournier M, Gagnon C, Sauvé S, et al. Ecotoxicity of CdTe quantum dots to freshwater mussels: impacts on immune system, oxidative stress and genotoxicity. Aquat Toxicol 2008;86:333-40.

27. Reeves JF, Davies SJ, Dodd NJ, Jha AN. Hydroxyl radicals $\left({ }^{*} \mathrm{OH}\right)$ are associated with titanium dioxide $(\mathrm{TiO}(2))$ nanoparticleinduced cytotoxicity and oxidative DNA damage in fish cells. Mutat Res 2008;640:113-22.

28. Vevers WF, Jha AN. Genotoxic and cytotoxic potential of titanium dioxide (TiO2) nanoparticles on fish cells in vitro. Ecotoxicology 2008;17:410-20.

29. Fabrega J, Luoma SN, Tyler CR, Galloway TS, Lead JR. Silver nanoparticles: behaviour and effects in the aquatic environment. Environ Int 2011;37:517-31.

30. Klaine SJ, Alvarez PJ, Batley GE, Fernandes TF, Handy RD, Lyon DY, et al. Nanomaterials in the environment: behavior, fate, bioavailability, and effects. Environ Toxicol Chem 2008;27:182551.

31. Oberdörster G, Oberdörster E, Oberdörster J. Concepts of nanoparticle dose metric and response metric. Environ Health Perspect 2007;115:A290.

32. Nowack B, Bucheli TD. Occurrence, behavior and effects of nanoparticles in the environment. Environ Pollut 2007;150:5-22.

33. Biswas P, Wu CY. Nanoparticles and the environment. J Air Waste Manag Assoc 2005;55:708-46.

34. Abdul-Khalek I, Kittelson D, Brear F. The influence of dilution conditions on diesel exhaust particle size distribution easurements. SAE Trans 1999;108:563-71.

35. Abdul-Khalek I, Kittelson D, Graskow B, Wei Q, Brear F. Diesel exhaust particle size: measurement issues and trends. SAE Trans 1998;107:683-96.

36. Mathis U, Ristimäki J, Mohr M, Keskinen J, Ntziachristos L, Samaras Z, et al. Sampling conditions for the measurement of nucleation mode particles in the exhaust of a diesel vehicle. Aerosol Sci Technol 2004;38:1149-60.

37. Morawska L, Ristovski Z, Jayaratne ER, Keogh DU, Ling $X$. Ambient nano and ultrafine particles from motor vehicle emissions: characteristics, ambient processing and implications on human exposure. Atmos Environ 2008;42:8113-38.

38. McMurry PH, Woo KS, Weber R, Chen DR, Pui DYH. Size distributions of 3-10 nm atmospheric particles: implications for nucleation mechanisms. Philos Trans R Soc A 2000;358:262542.

39. Shi JP, Evans DE, Khan AA, Harrison RM. Sources and concentration of nanoparticles ( $<10 \mathrm{~nm}$ diameter) in the urban atmosphere. Atmos Environ 2001;35:1193-202.

40. Wolny-Koładka KA, Malina DK. Silver nanoparticles toxicity against airborne strains of Staphylococcus spp. J Environ Sci Health A Tox Hazard Subst Environ Eng 2017;52:1247-56.

41. Baysal $A$, Saygin $H$, Ustabasi GS. Interaction of $\mathrm{PM}_{2.5}$ airborne particulates with $\mathrm{ZnO}$ and $\mathrm{TiO}_{2}$ nanoparticles and their effect on bacteria. Environ Monit Assess 2017;190:34.

42. Unrine JM, Hunyadi SE, Tsyusko OV, Rao W, Shoults-Wilson WA, Bertsch PM. Evidence for bioavailability of Au nanoparticles from soil and biodistribution within earthworms (Eisenia fetida). Environ Sci Technol 2010;44:8308-13.

43. Cameron FK. Soil colloids and the soil solution. J Phys Chem 1915;19:1-13.

44. Korcak RF, Fanning DS. Availability of applied heavy metals as a function of type of soil material and metal source. Soil Sci 1985;140:23-34.

45. Smolders E, Degryse F. Fate and effect of zinc from tire debris in soil. Environ Sci Technol 2002;36:3706-10.

46. Borm P, Klaessig FC, Landry TD, Moudgil B, Pauluhn J, Thomas K, et al. Research strategies for safety evaluation of nanomaterials, part V: role of dissolution in biological fate and effects of nanoscale particles. Toxicol Sci 2006;90:23-32.

47. Zhu Y, Zhao Q, Li Y, Cai X, Li W. The interaction and toxicity of multi-walled carbon nanotubes with Stylonychia mytilus. J Nanosci Nanotechnol 2006;6:1357-64.

48. Zhu H, Han J, Xiao JQ, Jin Y. Uptake, translocation, and accumulation of manufactured iron oxide nanoparticles by pumpkin plants. J Environ Monit 2008;10:713-7.

49. Molina MA, Ramos JL, Espinosa-Urgel M. A two-partner secretion system is involved in seed and root colonization and iron uptake by Pseudomonas putida KT2440. Environ Microbiol 2006;8:639-47.

50. Ramos-González MI, Campos MJ, Ramos JL. Analysis of Pseudomonas putida KT2440 gene expression in the maize rhizosphere: in vitro expression technology capture and identification of root-activated promoters. J Bacteriol 2005;187:4033-41.

51. Hardman R. A toxicologic review of quantum dots: toxicity depends on physicochemical and environmental factors. Environ Health Perspect 2006;114:165-72.

52. Gajjar P, Pettee B, Britt DW, Huang W, Johnson WP, Anderson AJ. Antimicrobial activities of commercial nanoparticles against an environmental soil microbe, Pseudomonas putida KT2440. J Biol Eng 2009;3:9.

53. Rizwan M, Ali S, Qayyum MF, Ok YS, Adrees M, Ibrahim M, et al. Effect of metal and metal oxide nanoparticles on growth and physiology of globally important food crops: a critical review. J Hazard Mater 2017;322(PtA):2-16.

54. Ma C, White JC, Dhankher OP, Xing B. Metal-based 
nanotoxicity and detoxification pathways in higher plants. Environ Sci Technol 2015;49:7109-22.

55. Zhao L, Sun Y, Hernandez-Viezcas JA, Hong J, Majumdar S, Niu G, et al. Monitoring the environmental effects of $\mathrm{CeO} 2$ and $\mathrm{ZnO}$ nanoparticles through the life cycle of corn (Zea mays) plants and in situ $\mu-X R F$ mapping of nutrients in kernels. Environ Sci Technol 2015;49:2921-8.

56. Vittori Antisari L, Carbone S, Gatti A, Vianello G, Nannipieri $\mathrm{P}$. Uptake and translocation of metals and nutrients in tomato grown in soil polluted with metal oxide $\left(\mathrm{CeO}_{2}, \mathrm{Fe}_{3} \mathrm{O}_{4}, \mathrm{SnO}_{2}\right.$, $\mathrm{TiO}_{2}$ ) or metallic (Ag, Co, Ni) engineered nanoparticles. Environ Sci Pollut Res Int 2015;22:1841-53.

57. Lapied E, Nahmani JY, Moudilou E, Chaurand P, Labille J, Rose $\mathrm{J}$, et al. Ecotoxicological effects of an aged $\mathrm{TiO}_{2}$ nanocomposite measured as apoptosis in the anecic earthworm Lumbricus terrestris after exposure through water, food and soil. Environ Int 2011;37:1105-10.

58. Zhao L, Hernandez-Viezcas JA, Peralta-Videa JR, Bandyopadhyay S, Peng B, Munoz B, et al. ZnO nanoparticle fate in soil and zinc bioaccumulation in corn plants (Zea mays) influenced by alginate. Environ Sci Process Impacts 2013;15:260-6.

59. Stegemeier JP, Schwab F, Colman BP, Webb SM, Newville M, Lanzirotti A, et al. Speciation matters: bioavailability of silver and silver sulfide nanoparticles to alfalfa (Medicago sativa). Environ Sci Technol 2015;49:8451-60.

60. Lei C, Sun Y, Tsang DCW, Lin D. Environmental transformations and ecological effects of iron-based nanoparticles. Environ Pollut 2018;232:10-30.

61. Auffan M, Bottero JY, Chaneac C, Rose J. Inorganic manufactured nanoparticles: how their physicochemical properties influence their biological effects in aqueous environments. Nanomedicine (Lond) 2010;5:999-1007.

62. Kennedy CB, Scott SD, Ferris FG. Hydrothermal phase stabilization of 2-line ferrihydrite by bacteria. Chem Geol 2004;212:269-77.

63. Simkiss K. Surface effects in ecotoxicology. Funct Ecol 1990;4:303-8.

64. Oberdörster E, Zhu S, Blickley TM, McClellan-Green P, Haasch ML. Ecotoxicology of carbon-based engineered nanoparticles: effects of fullerene (C60) on aquatic organisms. Carbon 2006;44:1112-20.

65. Kashiwada S. Distribution of nanoparticles in the seethrough medaka (Oryzias latipes). Environ Health Perspect 2006;114:1697-702.

66. Smith CJ, Shaw BJ, Handy RD. Toxicity of single walled carbon nanotubes to rainbow trout, (Oncorhynchus mykiss): respiratory toxicity, organ pathologies, and other physiological effects. Aquat Toxicol 2007;82:94-109.

67. Chen KL, Elimelech M. Influence of humic acid on the aggregation kinetics of fullerene ( 660$)$ nanoparticles in monovalent and divalent electrolyte solutions. J Colloid Interface Sci 2007;309:126-34.

68. Benn T, Cavanagh B, Hristovski K, Posner JD, Westerhoff P. The release of nanosilver from consumer products used in the home. J Environ Qual 2010;39:1875-82.

69. Lorenz C, Windler L, von Goetz N, Lehmann RP, Schuppler M, Hungerbühler $\mathrm{K}$, et al. Characterization of silver release from commercially available functional (nano)textiles. Chemosphere 2012;89:817-24.

70. Voelker D, Schlich K, Hohndorf L, Koch W, Kuehnen U, Polleichtner $\mathrm{C}$, et al. Approach on environmental risk assessment of nanosilver released from textiles. Environ Res 2015;140:661-72.

71. Kaegi R, Voegelin A, Sinnet B, Zuleeg S, Hagendorfer $H$, Burkhardt M, et al. Behavior of metallic silver nanoparticles in a pilot wastewater treatment plant. Environ Sci Technol 2011;45:3902-8.

72. Blaser SA, Scheringer M, Macleod M, Hungerbühler K. Estimation of cumulative aquatic exposure and risk due to silver: contribution of nano-functionalized plastics and textiles. Sci Total Environ 2008;390:396-409.

73. Gottschalk F, Sonderer T, Scholz RW, Nowack B. Modeled environmental concentrations of engineered nanomaterials (TiO(2), ZnO, Ag, CNT, Fullerenes) for different regions. Environ Sci Technol 2009;43:9216-22.

74. Bruneau A, Turcotte P, Pilote M, Gagné F, Gagnon C. Fate of silver nanoparticles in wastewater and immunotoxic effects on rainbow trout. Aquat Toxicol 2016;174:70-81.

75. Zhang J, Guo W, Li Q, Wang Z, Liu S. The effects and the potential mechanism of environmental transformation of metal nanoparticles on their toxicity in organisms. Environ Sci Nano 2018;5:2482-99.

76. Pachapur VL, Dalila Larios A, Cledón M, Brar SK, Verma M, Surampalli RY. Behavior and characterization of titanium dioxide and silver nanoparticles in soils. Sci Total Environ 2016;563564:933-43.

77. Londono N, Donovan AR, Shi H, Geisler M, Liang Y. Impact of $\mathrm{TiO}_{2}$ and $\mathrm{ZnO}$ nanoparticles on an aquatic microbial community: effect at environmentally relevant concentrations. Nanotoxicology 2017;11:1140-56.

78. El Badawy AM, Luxton TP, Silva RG, Scheckel KG, Suidan MT, Tolaymat TM. Impact of environmental conditions $(\mathrm{pH}$, ionic strength, and electrolyte type) on the surface charge and aggregation of silver nanoparticles suspensions. Environ Sci Technol 2010;44:1260-6.

79. Maurer-Jones MA, Gunsolus IL, Murphy CJ, Haynes CL. Toxicity of engineered nanoparticles in the environment. Anal Chem 2013;85:3036-49.

80. Moreno-Garrido I, Pérez S, Blasco J. Toxicity of silver and gold nanoparticles on marine microalgae. Mar Environ Res 2015;111:60-73.

81. Choi O, Hu Z. Size dependent and reactive oxygen species related nanosilver toxicity to nitrifying bacteria. Environ Sci Technol 2008;42:4583-8.

82. Matranga V, Corsi I. Toxic effects of engineered nanoparticles in the marine environment: model organisms and molecular approaches. Mar Environ Res 2012;76:32-40.

83. Kim KT, Zaikova T, Hutchison JE, Tanguay RL. Gold nano- 
particles disrupt zebrafish eye development and pigmentation. Toxicol Sci 2013;133:275-88.

84. Xue JY, Li X, Sun MZ, Wang YP, Wu M, Zhang CY, et al. An assessment of the impact of $\mathrm{SiO} 2$ nanoparticles of different sizes on the rest/wake behavior and the developmental profile of zebrafish larvae. Small 2013;9:3161-8.

85. Kwon JY, Koedrith P, Seo YR. Current investigations into the genotoxicity of zinc oxide and silica nanoparticles in mammalian models in vitro and in vivo: carcinogenic/genotoxic potential, relevant mechanisms and biomarkers, artifacts, and limitations. Int J Nanomedicine 2014;9 Suppl 2:271-86.

86. Carriere M, Sauvaigo S, Douki T, Ravanat JL. Impact of nanoparticles on DNA repair processes: current knowledge and working hypotheses. Mutagenesis 2017;32:203-13.

87. Magdolenova Z, Collins A, Kumar A, Dhawan A, Stone V, Dusinska M. Mechanisms of genotoxicity. A review of in vitro and in vivo studies with engineered nanoparticles. Nanotoxicology 2014;8:233-78.

88. Golbamaki N, Rasulev B, Cassano A, Marchese Robinson RL, Benfenati E, Leszczynski J, et al. Genotoxicity of metal oxide nanomaterials: review of recent data and discussion of possible mechanisms. Nanoscale 2015;7:2154-98.

89. Mahaye N, Thwala M, Cowan DA, Musee N. Genotoxicity of metal based engineered nanoparticles in aquatic organisms: a review. Mutat Res 2017;773:134-60.

90. Handy RD, van den Brink N, Chappell M, Mühling M, Behra $R$, Dušinská $M$, et al. Practical considerations for conducting ecotoxicity test methods with manufactured nanomaterials: what have we learnt so far? Ecotoxicology 2012;21:933-72.

91. Chen M, von Mikecz A. Formation of nucleoplasmic protein aggregates impairs nuclear function in response to $\mathrm{SiO} 2$ nanoparticles. Exp Cell Res 2005;305:51-62.

92. Nabiev I, Mitchell S, Davies A, Williams Y, Kelleher D, Moore R, et al. Nonfunctionalized nanocrystals can exploit a cell's active transport machinery delivering them to specific nuclear and cytoplasmic compartments. Nano Lett 2007;7:3452-61.

93. Toyokuni S. Oxidative stress and cancer: the role of redox regulation. Biotherapy 1998;11:147-54.

94. Valko M, Rhodes CJ, Moncol J, Izakovic M, Mazur M. Free radicals, metals and antioxidants in oxidative stress-induced cancer. Chem Biol Interact 2006;160:1-40.

95. Lee SW, Kim SM, Choi J. Genotoxicity and ecotoxicity assays using the freshwater crustacean Daphnia magna and the larva of the aquatic midge Chironomus riparius to screen the ecological risks of nanoparticle exposure. Environ Toxicol Pharmacol 2009;28:86-91.

96. Garcia-Reyero N, Thornton C, Hawkins AD, Escalon L, Kennedy AJ, Steevens JA, et al. Assessing the exposure to nanosilver and silver nitrate on fathead minnow gill gene expression and mucus production. Environ Nanotechnol Monit Manag 2015;4:58-66.

97. Mohmood I, Ahmad I, Asim M, Costa L, Lopes CB, Trindade $\mathrm{T}$, et al. Interference of the co-exposure of mercury with silicacoated iron oxide nanoparticles can modulate genotoxicity induced by their individual exposures--a paradox depicted in fish under in vitro conditions. Environ Sci Pollut Res Int 2015;22:3687-96.

98. Huang JT, Chan SH, Hou SY. Studies on the photokilling of E. coli with $\mathrm{TiO} 2$ nanoparticles by using gel electrophoresis technology. Tamkang J Sci Eng 2008;11:139-44.

99. Bondarenko O, Ivask A, Käkinen A, Kahru A. Sub-toxic effects of $\mathrm{CuO}$ nanoparticles on bacteria: kinetics, role of $\mathrm{Cu}$ ions and possible mechanisms of action. Environ Pollut 2012;169:81-9.

100. Kaweeteerawat C, Chang CH, Roy KR, Liu R, Li R, Toso D, et al. Cu nanoparticles have different impacts in Escherichia coli and Lactobacillus brevis than their microsized and ionic analogues. ACS Nano 2015;9:7215-25.

101. Ramesh R, Kavitha P, Kanipandian N, Arun S, Thirumurugan $R$, Subramanian P. Alteration of antioxidant enzymes and impairment of DNA in the SiO2 nanoparticles exposed zebra fish (Danio rerio). Environ Monit Assess 2013;185:5873-81.

102. Oberholster PJ, Musee N, Botha AM, Chelule PK, Focke WW, Ashton PJ. Assessment of the effect of nanomaterials on sediment-dwelling invertebrate Chironomus tentans larvae. Ecotoxicol Environ Saf 2011;74:416-23.

103. Kim SM, Choi J. Genotoxicity of $\mathrm{CeO}_{2}, \mathrm{SiO}_{2}$ and $\mathrm{TiO}_{2}$ nanoparticles in the freshwater crustacean Daphnia magna. $\mathrm{J}$ Environ Toxicol 2008;23:79-85.

104. Poynton HC, Lazorchak JM, Impellitteri CA, Blalock BJ, Rogers $\mathrm{K}$, Allen $\mathrm{HJ}$, et al. Toxicogenomic responses of nanotoxicity in Daphnia magna exposed to silver nitrate and coated silver nanoparticles. Environ Sci Technol 2012;46:6288-96.

105. Canesi L, Frenzilli G, Balbi T, Bernardeschi M, Ciacci C, Corsolini S, et al. Interactive effects of n-TiO2 and 2,3,7,8-TCDD on the marine bivalve Mytilus galloprovincialis. Aquat Toxicol 2014;153:53-65.

106. Fang $Q$, Shi X, Zhang L, Wang Q, Wang X, Guo $Y$, et al. Effect of titanium dioxide nanoparticles on the bioavailability, metabolism, and toxicity of pentachlorophenol in zebrafish larvae. J Hazard Mater 2015;283:897-904.

107. Falfushynska H, Gnatyshyna L, Yurchak I, Sokolova I, Stoliar O. The effects of zinc nanooxide on cellular stress responses of the freshwater mussels Unio tumidus are modulated by elevated temperature and organic pollutants. Aquat Toxicol 2015;162:8293.

108. Farkas J, Bergum S, Nilsen EW, Olsen AJ, Salaberria I, Ciesielski TM, et al. The impact of $\mathrm{TiO} 2$ nanoparticles on uptake and toxicity of benzo(a)pyrene in the blue mussel (Mytilus edulis). Sci Total Environ 2015;511:469-76.

109. Ali D. Oxidative stress-mediated apoptosis and genotoxicity induced by silver nanoparticles in freshwater snail Lymnea luteola L. Biol Trace Elem Res 2014;162:333-41.

110. Cumberland SA, Lead JR. Particle size distributions of silver nanoparticles at environmentally relevant conditions. J Chromatogr A 2009;1216:9099-105.

111. von der Kammer F, Ottofuelling S, Hofmann T. Assessment of the physico-chemical behavior of titanium dioxide nanoparticles in aquatic environments using multi-dimensional parameter 
Koedrith et al.

testing. Environ Pollut 2010;158:3472-81.

112. Ottofuelling S, Von der Kammer F, Hofmann T. Commercial titanium dioxide nanoparticles in both natural and synthetic water: comprehensive multidimensional testing and prediction of aggregation behavior. Environ Sci Technol 2011;45:10045-52.

113. Li X, Lenhart JJ, Walker HW. Dissolution-accompanied aggregation kinetics of silver nanoparticles. Langmuir 2010;26:16690-8.

114. Li X, Lenhart JJ, Walker HW. Aggregation kinetics and dissolution of coated silver nanoparticles. Langmuir 2012;28:1095104.

115. Huynh KA, Chen KL. Aggregation kinetics of citrate and polyvinylpyrrolidone coated silver nanoparticles in monovalent and divalent electrolyte solutions. Environ Sci Technol 2011;45:5564-71.

116. Zhang W, Yao Y, Li K, Huang Y, Chen Y. Influence of dissolved oxygen on aggregation kinetics of citrate-coated silver nanoparticles. Environ Pollut 2011;159:3757-62.

117. Zhang H, Smith JA, Oyanedel-Craver V. The effect of natural water conditions on the anti-bacterial performance and stability of silver nanoparticles capped with different polymers. Water Res 2012;46:691-9.

118. Piccapietra F, Sigg L, Behra R. Colloidal stability of carbonatecoated silver nanoparticles in synthetic and natural freshwater. Environ Sci Technol 2012;46:818-25.

119. Batley GE, Kirby JK, McLaughlin MJ. Fate and risks of nanomaterials in aquatic and terrestrial environments. Acc Chem Res 2013;46:854-62.

120. Selck H, Handy RD, Fernandes TF, Klaine SJ, Petersen EJ. Nanomaterials in the aquatic environment: a European UnionUnited States perspective on the status of ecotoxicity testing, research priorities, and challenges ahead. Environ Toxicol Chem 2016;35:1055-67.

121. Yu R, Wu J, Liu M, Zhu G, Chen L, Chang Y, et al. Toxicity of binary mixtures of metal oxide nanoparticles to Nitrosomonas europaea. Chemosphere 2016;153:187-97.

122. Załęska-Radziwiłł M, Doskocz N. DNA changes in Pseudomonas putida induced by aluminum oxide nanoparticles using RAPD analysis. Desalination Water Treat 2016;57:157381.

123. Rajkishore SK, Subramanian KS, Natarajan N, Gunasekaran K. Nanotoxicity at various trophic levels: a review. Bioscan 2013;8:975-82.

124. Fariba A, Bahram GE, Farrokh K, Tabrizy S, Pooneh SS. An investigation of the effect of copper oxide and silver nanoparticles on E. coli genome by rapd molecular markers. Adv Biotech Micro 2016;1:555559.

125. Doak SH, Manshian B, Jenkins GJ, Singh N. In vitro genotoxicity testing strategy for nanomaterials and the adaptation of current OECD guidelines. Mutat Res 2012;745:104-11.

126. Warheit DB, Hoke RA, Finlay C, Donner EM, Reed KL, Sayes CM. Development of a base set of toxicity tests using ultrafine $\mathrm{TiO} 2$ particles as a component of nanoparticle risk management. Toxicol Lett 2007;171:99-110.
127. Lopes I, Ribeiro R, Antunes FE, Rocha-Santos TA, Rasteiro MG, Soares AM, et al. Toxicity and genotoxicity of organic and inorganic nanoparticles to the bacteria Vibrio fischeri and Salmonella typhimurium. Ecotoxicology 2012;21:637-48.

128. Ko KS, Kong IC. Toxic effects of nanoparticles on bioluminescence activity, seed germination, and gene mutation. Appl Microbiol Biotechnol 2014;98:3295-303.

129. Chen YT, Wu JH, Tsai FJ, Chang YW, Hsu SH, Lin JJ, et al. Genotoxicity tests of poly(styrene-co-maleic anhydride)coated silver nanoparticles in vivo and in vitro. J Exp Nanosci 2015;10:449-57.

130. Landsiedel R, Kapp MD, Schulz M, Wiench K, Oesch F. Genotoxicity investigations on nanomaterials: methods, preparation and characterization of test material, potential artifacts and limitations--many questions, some answers. Mutat Res 2009;681:241-58.

131. Oesch F, Landsiedel R. Genotoxicity investigations on nanomaterials. Arch Toxicol 2012;86:985-94.

132. George JM, Magogotya M, Vetten MA, Buys AV, Gulumian $M$. From the cover: an investigation of the genotoxicity and interference of gold nanoparticles in commonly used in vitro mutagenicity and genotoxicity assays. Toxicol Sci 2017;156:14966

133. Bajpayee M, Kumar A, Dhawan A. The comet assay: assessment of in vitro and in vivo DNA damage. In: Dhawan A, Bajpayee M, eds. Genotoxicity Assessment. Totowa, Humana Press, pp 325-45, 2013.

134. Kumar A, Sharma V, Dhawan A. Methods for detection of oxidative stress and genotoxicity of engineered nanoparticles. In: Armstrong D, Bharali DJ, eds. Oxidative Stress and Nanotechnology. Totowa, Humana Press, pp 231-46, 2013.

135. Pavanello S, Clonfero E. Biological indicators of genotoxic risk and metabolic polymorphisms. Mutat Res 2000;463:285-308.

136. Collins AR, Oscoz AA, Brunborg G, Gaivão I, Giovannelli L, Kruszewski $\mathrm{M}$, et al. The comet assay: topical issues. Mutagenesis 2008;23:143-51.

137. Kumar A, Dhawan A. Genotoxic and carcinogenic potential of engineered nanoparticles: an update. Arch Toxicol 2013; 87:1883-900.

138. Collins AR. The comet assay for DNA damage and repair: principles, applications, and limitations. Mol Biotechnol 2004;26:249-61.

139. Karlsson HL. The comet assay in nanotoxicology research. Anal Bioanal Chem 2010;398:651-66.

140. Verschaeve L, Gilles J. Single cell gel electrophoresis assay in the earthworm for the detection of genotoxic compounds in soils. Bull Environ Contam Toxicol 1995;54:112-9.

141. Dixon DR, Pruski AM, Dixon LR, Jha AN. Marine invertebrate eco-genotoxicology: a methodological overview. Mutagenesis 2002;17:495-507.

142. de Lapuente J, Lourenço J, Mendo SA, Borràs M, Martins MG, Costa PM, et al. The Comet Assay and its applications in the field of ecotoxicology: a mature tool that continues to expand its perspectives. Front Genet 2015;6:180. 
143. Oberholster PJ, Hill L, Jappie S, Truter JC, Botha AM. Applying genotoxicology tools to identify environmental stressors in support of river management. Chemosphere 2016;144:319-29.

144. Tice RR, Agurell E, Anderson D, Burlinson B, Hartmann A, Kobayashi $\mathrm{H}$, et al. Single cell gel/comet assay: guidelines for in vitro and in vivo genetic toxicology testing. Environ Mol Mutagen 2000;35:206-21.

145. Sharma V, Anderson D, Dhawan A. Zinc oxide nanoparticles induce oxidative DNA damage and ROS-triggered mitochondria mediated apoptosis in human liver cells (HepG2). Apoptosis 2012;17:852-70.

146. Bolognesi C, Cirillo S. Genotoxicity biomarkers in aquatic bioindicators. Curr Zool 2014;60:273-84.

147. Schiavo S, Oliviero M, Miglietta M, Rametta G, Manzo S. Genotoxic and cytotoxic effects of $\mathrm{ZnO}$ nanoparticles for Dunaliella tertiolecta and comparison with $\mathrm{SiO} 2$ and $\mathrm{TiO} 2$ effects at population growth inhibition levels. Sci Total Environ 2016;550:619-27.

148. Fenech $M$. The in vitro micronucleus technique. Mutat Res 2000;455:81-95.

149. Kirkland D, Reeve L, Gatehouse D, Vanparys P. A core in vitro genotoxicity battery comprising the Ames test plus the in vitro micronucleus test is sufficient to detect rodent carcinogens and in vivo genotoxins. Mutat Res 2011;721:27-73.

150. Doherty A, Bryce SM, Bemis JC. The in vitro micronucleus assay. In: Proudlock R, ed. Genetic Toxicology Testing. London, Academic Press, pp 161-205, 2016.

151. Doak SH, Griffiths SM, Manshian B, Singh N, Williams PM, Brown AP, et al. Confounding experimental considerations in nanogenotoxicology. Mutagenesis 2009;24:285-93.

152. Li Y, Doak SH, Yan J, Chen DH, Zhou M, Mittelstaedt RA, et al. Factors affecting the in vitro micronucleus assay for evaluation of nanomaterials. Mutagenesis 2017;32:151-9.

153. Van Goethem F, Lison D, Kirsch-Volders M. Comparative evaluation of the in vitro micronucleus test and the alkaline single cell gel electrophoresis assay for the detection of DNA damaging agents: genotoxic effects of cobalt powder, tungsten carbide and cobalt-tungsten carbide. Mutat Res 1997;392:3143.

154. Kang SJ, Kim BM, Lee YJ, Chung HW. Titanium dioxide nanoparticles trigger p53-mediated damage response in peripheral blood lymphocytes. Environ Mol Mutagen 2008;49:399-405.

155. Wang JJ, Sanderson BJ, Wang H. Cyto- and genotoxicity of ultrafine $\mathrm{TiO} 2$ particles in cultured human lymphoblastoid cells. Mutat Res 2007;628:99-106.

156. Pacurari M, Yin XJ, Zhao J, Ding M, Leonard SS, SchweglerBerry $D$, et al. Raw single-wall carbon nanotubes induce oxidative stress and activate MAPKs, AP-1, NF-kappaB, and Akt in normal and malignant human mesothelial cells. Environ Health Perspect 2008;116:1211-7.

157. Gopalan RC, Osman IF, Amani A, De Matas M, Anderson D. The effect of zinc oxide and titanium dioxide nanoparticles in the Comet assay with UVA photoactivation of human sperm and lymphocytes. Nanotoxicology 2009;3:33-9.

158. De Jong WH, Hagens WI, Krystek P, Burger MC, Sips AJ, Geertsma RE. Particle size-dependent organ distribution of gold nanoparticles after intravenous administration. Biomaterials 2008;29:1912-9.

159. Takeda K, Suzuki K, Ishihara A, Kubo-Irie M, Fujimoto R, Tabata $M$, et al. Nanoparticles transferred from pregnant mice to their offspring can damage the genital and cranial nerve systems. J Health Sci 2009;55:95-102.

160. Colognato R, Bonelli A, Ponti J, Farina M, Bergamaschi E, Sabbioni E, et al. Comparative genotoxicity of cobalt nanoparticles and ions on human peripheral leukocytes in vitro. Mutagenesis 2008;23:377-82.

161. Gonzalez L, Lison D, Kirsch-Volders M. Genotoxicity of engineered nanomaterials: a critical review. Nanotoxicology 2008;2:252-73. 